\title{
VIVIANITE AND SIDERITE IN LATERITIC IRON CRUST: AN EXAMPLE OF BIOREDUCTION
}

\author{
Vanda Porpino Lemos*, Marcondes Lima da Costa e Ronaldo Lima Lemos \\ Centro de Geociências da Universidade Federal do Pará, Rua Augusto Corrêa, 1, 66075-090 Belém - PA, Brasil \\ Mario Sergio Gomes de Faria \\ Companhia de Pesquisa de Recursos Minerais, Manaus - AM, Brasil
}

Recebido em 15/9/05; aceito em 25/4/06; publicado na web em 30/8/06

\begin{abstract}
Lateritic iron crust (LIC) samples from Padauari (AM) were analysed by XRD, optical microscopy and SEM-EDS. The equilibrium of iron minerals (IM) was studied using Eh-pH diagram. It was shown that the minerals of the LIC are goethite $(\alpha-\mathrm{FeOOH})$, vivianite $\left[\mathrm{Fe}_{3}\left(\mathrm{PO}_{4}\right)_{2} \cdot 8 \mathrm{H}_{2} \mathrm{O}\right]$ and siderite $\left(\mathrm{FeCO}_{3}\right)$. Carbonate grains are a solid solution of $\mathrm{FeCO}_{3}-\mathrm{MnCO}_{3}$. The LIC presents textures and structures of dissolution of IM. The siderite and vivianite are stable from $\mathrm{Eh}=-0.3$ to $0.0 \mathrm{~V}$ and $\mathrm{pH}=5.0-7.5$. These results indicate that vivianite and siderite are products of bioreduction through biogenic dissolution of IM, the new conditions of ecosystems of the Amazon region.
\end{abstract}

Keywords: bioreduction; siderite; vivianite.

\section{INTRODUCTION}

Lakes and swamps, where there is acumulation of organic matter, the microoganisms influence the course of reactions involving dissolutions of iron minerals, like goethite $(\alpha-\mathrm{FeOOH})$ and hematite $\left(\alpha-\mathrm{Fe}_{2} \mathrm{O}_{3}\right)^{1,2}$. Microorganisms play an important role in the natural environment by determining the speciation of Fe. They can also cause considerable Fe accumulation through biomineralization. These microorganisms obtain their energy by electron transfer from a reduced species to an oxidized one. The most common electron acceptor in the natural environment is $\mathrm{Fe}$, and because of its widespread abundance groundwaters are generally reduced due to the activity of the Fe-reducing bacteria ${ }^{3,4}$.

Microbiologic reduction of $\mathrm{Fe}^{3+}$ oxides associated with organic matter were investigated using dissimulatory metal reducing bacteria (DMRB) in bicarbonate buffer, phosphate and anthraquinone- 2, 6dissulfonate (AQDS), a humic acid analogue. Under anoxic conditions the microorganisms can use $\mathrm{Fe}^{3+}$ or $\mathrm{Mn}^{4+}$ as electron acceptors coupled to the oxidation of organic matter and gain energy for maintenance and growth from such reactions ${ }^{3}$. DMRB are common in groundwaters, lakes, swamps and sediments and influence the aqueous geochemistry, surface chemistry and mineralogy of these environments ${ }^{2,3,5}$. The formation of siderite, magnetite and vivianite are generally attributed to the activity of $\mathrm{DMRB}^{6}$.

The purpose of this work is to show an example of microbial oxidation coupled to $\mathrm{Fe}^{3+}$ reduction ocurring in lateritic iron crust submitted to lakes and swamp environment located at Padauari, Amazon region, Brazil where it has been observed the formation of the pair vivianite-siderite. The formation of these minerals is discussed here and is interpreted on the basis chemical equilibrium studies.

\section{EXPERIMENTAL}

\section{Sampling}

The samples used in the study were colletected at Padauari region in the Barcelos province, State of Amazonas, Brazil. This

*e-mail: vplemos@ufpa.br region is dominated by swamps and lakes, which make a typical hydromorphic environment, developed over lateritic terrains representd by iron crust and latosols ${ }^{7,8}$.

\section{Analytical techniques}

The samples were analized by optical microscopy, X-ray diffraction (XRD), using a Philips model PW 3710 diffractometer and $\mathrm{Ni}$-filtered $\mathrm{CuK} \alpha$ radiation, scanning electron microscopy (SEM) and energy dispersive spectroscopy (EDS).

\section{Construction of the Eh-pH diagram}

The study about stability fields of the iron minerals were based: equilibrium relationship in system $\mathrm{Fe}+\mathrm{H}_{2} \mathrm{O}+\mathrm{O}_{2}$ at $25{ }^{\circ} \mathrm{C}$ and 1 atm; $\Delta \mathrm{G}^{\circ}$ and $\mathrm{E}^{\circ}$ values reported by Garrels and Christ ${ }^{9}$, Wagman et al. ${ }^{10}$ and Brookins ${ }^{11}$; half-reactions relating the iron minerals, vivianite $\left[\mathrm{Fe}_{3}\left(\mathrm{PO}_{4}\right)_{2} \cdot 8 \mathrm{H}_{2} \mathrm{O}\right]$, siderite $\left(\mathrm{FeCO}_{3}\right)$ and aqueous species ${ }^{12}$ (Table 1). The mechanics of constructing Eh-pH diagram is illustrated by a detailed development of half-reactions, equations and calculations showing the stability limits of water; the stability of iron oxides and stability relations of iron hydroxides and activities of ions in equilibrium with iron oxides.

\section{The stability of water}

The upper limit of water stability was determined as the equilibrium between water and oxygen at $\mathrm{P}=1 \mathrm{~atm}$. This relation is shown by reaction (1) and Equations (1-5) and can be plotted wich $\mathrm{Eh}$ and $\mathrm{pH}$ as ordinate and abscissa, respectively.

$$
2 \mathrm{H}_{2} \mathrm{O}(l) \rightleftharpoons \mathrm{O}_{2}+4 \mathrm{H}^{+}+4 \mathrm{e}
$$

The corresponding half-cell potential is given by

$$
E h=E^{o}+\frac{R T}{n F} \ln \frac{[\text { oxidizedstate }]}{[\text { reducedstate }]}
$$

Here Eh is the half-cell potential relative to the standard hydrogen electrode; $\mathrm{E}^{\mathrm{o}}$ is the standard half-cell potential, i.e., the 
Table 1. Half-reactions relating the iron minerals, vivianite, siderite and the aqueous species, ref. $12 . \Delta \mathrm{G}^{\circ}$ and $\mathrm{E}^{\circ}$ data are from ref. 9 and ref. 10

\begin{tabular}{|c|c|}
\hline Couple & Half-reactions \\
\hline $\mathrm{Fe}_{3} \mathrm{O}_{4} / \mathrm{Fe}$ & $\mathrm{Fe}_{3} \mathrm{O}_{4}+8 \mathrm{H}^{+}+8 \mathrm{e}^{-} \rightarrow 3 \mathrm{Fe}+4 \mathrm{H}_{2} \mathrm{O}$ \\
\hline $\mathrm{Fe}_{2} \mathrm{O}_{3} / \mathrm{Fe}_{3} \mathrm{O}_{4}$ & $3 \mathrm{Fe}_{2} \mathrm{O}_{3}+2 \mathrm{H}^{+}+2 \mathrm{e}^{-} \rightarrow 2 \mathrm{Fe}_{3} \mathrm{O}_{4}+\mathrm{H}_{2} \mathrm{O}$ \\
\hline $\mathrm{Fe}^{3+} / \mathrm{Fe}_{3} \mathrm{O}_{4}$ & $3 \mathrm{Fe}^{3+}+4 \mathrm{H}_{2} \mathrm{O}+\mathrm{e}^{-} \rightarrow \mathrm{Fe}_{3} \mathrm{O}_{4}+8 \mathrm{H}^{+}$ \\
\hline $\mathrm{Fe}^{3+} / \mathrm{Fe}^{2+}$ & $\mathrm{Fe}^{3+}+\mathrm{e}^{-} \rightarrow \mathrm{Fe}^{2+}$ \\
\hline $\mathrm{Fe}(\mathrm{OH})_{3} / \mathrm{Fe}^{2+}$ & $\mathrm{Fe}(\mathrm{OH})_{3}+3 \mathrm{H}^{+}+\mathrm{e}^{-} \rightarrow \mathrm{Fe}^{2+}+3 \mathrm{H}_{2} \mathrm{O}$ \\
\hline $\mathrm{Fe}_{2} \mathrm{O}_{3} / \mathrm{Fe}^{2+}$ & $\mathrm{Fe}_{2} \mathrm{O}_{3}+6 \mathrm{H}^{+}+2 \mathrm{e}^{-} \rightarrow 2 \mathrm{Fe}^{2+}+3 \mathrm{H}_{2} \mathrm{O}$ \\
\hline $\mathrm{Fe}^{3+} / \mathrm{Fe}_{2} \mathrm{O}_{3}$ & $2 \mathrm{Fe}^{3+}+3 \mathrm{H}_{2} \mathrm{O} \rightarrow \mathrm{Fe}_{2} \mathrm{O}_{3}+6 \mathrm{H}^{+}$ \\
\hline $\mathrm{FeOH}^{++} / \mathrm{Fe}_{2} \mathrm{O}_{3}$ & $2 \mathrm{FeOH}^{++}+\mathrm{H}_{2} \mathrm{O} \rightarrow \mathrm{Fe}_{2} \mathrm{O}_{3}+4 \mathrm{H}^{+}$ \\
\hline $\mathrm{Fe}_{2} \mathrm{O}_{3} / \mathrm{Fe}(\mathrm{OH})_{2}^{+}$ & $\mathrm{Fe}_{2} \mathrm{O}_{3}+\mathrm{H}_{2} \mathrm{O}+2 \mathrm{H}^{+} \rightarrow 2 \mathrm{Fe}(\mathrm{OH})_{2}^{+}$ \\
\hline $\mathrm{FeOH}^{++} / \mathrm{Fe}_{3} \mathrm{O}_{4}$ & $3 \mathrm{FeOH}^{++} \mathrm{H}_{2} \mathrm{O}+\mathrm{e}^{-} \rightarrow \mathrm{Fe}_{3} \mathrm{O}_{4}+5 \mathrm{H}^{+}$ \\
\hline $\mathrm{Fe}_{3} \mathrm{O}_{4} / \mathrm{FeOH}^{+}$ & $\mathrm{Fe}_{3} \mathrm{O}_{4}+5 \mathrm{H}^{+}+2 \mathrm{e}^{-} \rightarrow 3 \mathrm{FeOH}^{+}+\mathrm{H}_{2} \mathrm{O}$ \\
\hline $\mathrm{Fe}_{2}^{3} \mathrm{O}_{3}^{4} / \mathrm{FeOH}^{+}$ & $\mathrm{Fe}_{2}^{3} \mathrm{O}_{3}^{4}+4 \mathrm{H}^{+}+2 \mathrm{e}^{-} \rightarrow 2 \mathrm{FeOH}^{+}+\mathrm{H}_{2}^{2} \mathrm{O}$ \\
\hline Vivian./Fe $\mathrm{Fe}^{2+}$ & $\begin{array}{l}\mathrm{Fe}_{3}^{2}\left(\mathrm{PO}_{4}\right)_{2} \cdot 8 \mathrm{H}_{2} \mathrm{O}+2 \mathrm{H}^{+} \rightarrow 3 \mathrm{Fe}^{2+}+2 \mathrm{HPO}^{2-} \\
+8 \mathrm{H}_{2} \mathrm{O}+\mathrm{H}^{+}\end{array}$ \\
\hline Vivian./siderite & $\begin{array}{l}\mathrm{Fe}_{3}\left(\mathrm{PO}_{4}\right)_{2} \cdot 8 \mathrm{H}_{2} \mathrm{O}+3 \mathrm{HCO}_{3}^{-} \rightarrow 3 \mathrm{FeCO}_{3} \\
+2 \mathrm{HPO}_{4}^{2-}+8 \mathrm{H}\end{array}$ \\
\hline Vivian./Fe $(\mathrm{OH})_{2}$ & $\begin{array}{l}\mathrm{Fe}_{3}\left(\mathrm{PO}_{4}\right)_{2} \cdot 8 \mathrm{H}_{2} \mathrm{O} \rightarrow 3 \mathrm{Fe}(\mathrm{OH})_{2}+2 \mathrm{HPO}_{4}^{2-} \\
+4 \mathrm{H}^{+}+2 \mathrm{H}_{2} \mathrm{O}\end{array}$ \\
\hline Vivian./FeS & $\begin{array}{l}\mathrm{Fe}_{3}\left(\mathrm{PO}_{4}\right)_{2} \cdot 8 \mathrm{H}_{2}^{2} \mathrm{O}+3 \mathrm{HS}^{-} \rightarrow 3 \mathrm{FeS}+2 \mathrm{HPO}_{4}^{2-} \\
+\mathrm{H}^{+}+8 \mathrm{H}_{2} \mathrm{O}\end{array}$ \\
\hline $\mathrm{Fe}(\mathrm{OH})_{3} / \mathrm{FeS}_{2}$ & $\mathrm{Fe}(\mathrm{OH})_{3}+2 \mathrm{HS}^{-}+2 \mathrm{H}^{+}+\mathrm{e}^{-} \rightarrow \mathrm{FeS}_{2}+3 \mathrm{H}_{2} \mathrm{O}$ \\
\hline $\mathrm{Fe}(\mathrm{OH})_{3} / \mathrm{FeS}$ & $\mathrm{Fe}(\mathrm{OH})_{3}+\mathrm{HS}^{-}+2 \mathrm{H}^{+}+\mathrm{e}^{-} \rightarrow \mathrm{FeS}^{2}+3 \mathrm{H}_{2} \mathrm{O}^{2}$ \\
\hline $\mathrm{FeS} / \mathrm{Fe}(\mathrm{OH})_{2}$ & $\mathrm{FeS}+2 \mathrm{H}_{2} \mathrm{O} \rightarrow \mathrm{Fé}(\mathrm{OH})_{2}+\mathrm{H}_{2} \mathrm{~S}$ \\
\hline $\mathrm{Fe}^{2+} / \mathrm{FeCO}_{3}$ & $\mathrm{Fe}^{2+}+\mathrm{HCO}_{3}^{-} \rightarrow \mathrm{FeCO}_{3}+\mathrm{H}^{+}$ \\
\hline $\mathrm{Fe}(\mathrm{OH})_{3} / \mathrm{Fe} \mathrm{CO}_{3}$ & $\begin{array}{l}\mathrm{Fe}(\mathrm{OH})_{3}+\mathrm{HCO}_{3}^{-}+2 \mathrm{H}^{+}+\mathrm{e}^{-} \rightarrow \mathrm{FeCO}_{3} \\
+3 \mathrm{H}_{2} \mathrm{O}\end{array}$ \\
\hline $\mathrm{Fe}(\mathrm{OH})_{3} / \mathrm{Fe}^{2+}$ & $\mathrm{Fe}(\mathrm{OH})_{3}+3 \mathrm{H}^{+}+\mathrm{e}^{-} \rightarrow \mathrm{Fe}^{2}+3 \mathrm{H}_{2} \mathrm{O}$ \\
\hline $\mathrm{Fe}(\mathrm{OH})_{3} / \mathrm{Fe}(\mathrm{OH})_{2}$ & $\mathrm{Fe}(\mathrm{OH})_{3}+\mathrm{H}^{+}+\mathrm{e}^{-} \rightarrow \mathrm{Fe}(\mathrm{OH})_{2}+\mathrm{H}_{2} \mathrm{O}$ \\
\hline
\end{tabular}

voltage of the half-cell when the activities are unity for all species entering into the half-reaction.

For the half-reaction

$\mathrm{aA}+\mathrm{bB} \rightleftharpoons \mathrm{cC}+\mathrm{dD}+\mathrm{ne}$

(1) yields, for $25^{\circ} \mathrm{C}$,

$E h=E^{o}+\frac{0.0592}{n} \log \frac{[C]^{c}}{[A]^{a}} \frac{[D]^{d}}{[B]^{b}}$

All calculation in the following are made $25^{\circ} \mathrm{C}$ and 1 atmosphere total pressure; activities of pure solids and pure liquids are taken to be unity, and the activity of a gas phase is taken to be iqual to its pressure. From reaction (1)

$E h=E^{o}+\frac{0.0592}{4} \log \left[H^{+}\right]^{4}$

To obtain $\mathrm{E}^{\circ}$ for the reaction, the standard free energy is obtained and is substituted in Equation (4)

$E^{o}=\frac{\Delta G_{r}^{o}}{n F}$

First, the standard free energy is obtained

$$
\begin{aligned}
& 2 \mathrm{H}_{2} \mathrm{O}(l) \rightleftharpoons \mathrm{O}_{2}(\mathrm{~g})+4 \mathrm{H}^{+}+4 e \\
& \left(\Delta \mathrm{G}^{\mathrm{o}}\right)_{\mathrm{r}}=\Sigma\left(\Delta \mathrm{G}^{\mathrm{o}}\right)_{\text {produtos }}-\Sigma\left(\Delta \mathrm{G}^{\mathrm{o}}\right)_{\text {reagentes }}
\end{aligned}
$$

$\left(\Delta \mathrm{G}^{\circ}\right)_{\mathrm{s}}=-(2 \mathrm{x}-56.69)=113.4 \mathrm{kcal}$

Substituting in (4)

$E^{o}=\frac{113.4}{4 \times 23.06}=1.23$ volts

The final equation is

$\mathrm{Eh}=1.23-0.059 \mathrm{pH}$

The lower limit of water stability was determined as the equilibrium between $\mathrm{H}_{2}$ and $\mathrm{H}^{+}$at $\mathrm{P}=1 \mathrm{~atm}$.

$\mathrm{H}_{2}(\mathrm{~g}) \rightleftharpoons 2 \mathrm{H}^{+}+2 e(3) ; \mathrm{E}^{\mathrm{o}}=0$

$E h=\frac{0.059}{2} \log \frac{\left[H^{+}\right]^{2}}{p H_{2}}=-0.059 \times \mathrm{pH}$

\section{The stability of iron oxides}

The stable iron phases are native iron, magnetite $\left(\mathrm{Fe}_{3} \mathrm{O}_{4}\right)$ and hematite $\left(\alpha-\mathrm{Fe}_{2} \mathrm{O}_{3}\right)$.

For the oxidation of native iron to magnetite

$3 \mathrm{Fe}+2 \mathrm{O}_{2}(\mathrm{~g}) \rightleftharpoons \mathrm{Fe}_{3} \mathrm{O}_{4}$

$4 \mathrm{H}_{2} \mathrm{O}(l) \rightleftharpoons 8 \mathrm{H}^{+}+2 \mathrm{O}_{2}+8 e$

$3 \mathrm{Fe}+4 \mathrm{H}_{2} \mathrm{O}(l) \rightleftharpoons \mathrm{Fe}_{3} \mathrm{O}_{4}+8 \mathrm{H}^{+}+8 e$

The standard free energy of reaction (5) is

$\left(\Delta \mathrm{G}^{\mathrm{o}}\right)_{\mathrm{r}}=\Sigma\left(\Delta \mathrm{G}^{\mathrm{o}}\right)_{\text {produtos }}-\Sigma\left(\Delta \mathrm{G}^{\circ}\right)_{\text {reagentes }}$

$\left(\Delta \mathrm{G}^{\mathrm{o}}\right)_{\mathrm{r}}=-242.4+(8 \times 0)-(3 \times 0)-(4 \times-56,69)=-15.6 \mathrm{kcal}$

$E^{o}=\frac{-15.6}{8 \times 23.06}=-0.084$

$E h=-0.084+\frac{0.059}{8} \log \frac{\left[H^{+}\right]^{8}}{1}$

Substituting $-\mathrm{pH}$ for $\log \left[\mathrm{H}^{+}+\right]$

$\mathrm{Eh}=-0.084-0.059 \mathrm{pH}$

The reaction between native iron and magnetite is a straight line on the Eh-pH plot, and has the same slope as the water stability boundary lines. This reaction lies below the lower limit of water stability, and therefore the reaction cannot take place stably in the presence of water.

For the oxidation of magnetite to hematite

$2 \mathrm{Fe}_{3} \mathrm{O}_{4}+1 / 2 \mathrm{O}_{2}(\mathrm{~g}) \rightleftharpoons 3 \mathrm{Fe}_{2} \mathrm{O}_{3}$

$\mathrm{H}_{2} \mathrm{O}(l) \rightleftharpoons 2 \mathrm{H}^{+}+1 / 2 \mathrm{O}_{2}(\mathrm{~g})+2 e$

$2 \mathrm{Fe}_{3} \mathrm{O}_{4}+\mathrm{H}_{2} \mathrm{O}(l) \rightleftharpoons 3 \mathrm{Fe}_{2} \mathrm{O}_{3}+2 \mathrm{H}^{+}+2 e$

$\left(\Delta \mathrm{G}^{\mathrm{o}}\right)_{\mathrm{r}}=(3 \mathrm{x}-177.1)-(2 \mathrm{x}-242.4)-(-56.69)=10.2 \mathrm{kcal}$

$E^{o}=\frac{10.2}{2 \times 23.06}=0.221$ volt 
$E h=0.221+\frac{0.059}{2} \log \left[H^{+}\right]^{2}$

$\mathrm{Eh}=0.221-0.059 \mathrm{pH}$

\section{Stability relation of iron hydroxides}

For the relation between ferric hydroxide (this precipitate is unstable with respect to both hematite and goethite) and hematite

$2 \mathrm{Fe}(\mathrm{OH})_{3} \rightleftharpoons \mathrm{Fe}_{2} \mathrm{O}_{3}+3 \mathrm{H}_{2} \mathrm{O}(l)$

$\left(\Delta \mathrm{G}^{\mathrm{o}}\right)_{\mathrm{r}}=-177.1+(3 \mathrm{x}-56,69)-(2 \times 166.0)=-15,17 \mathrm{kcal}$.

Thus, with sufficient time, the precipitated ferric hydroxide will convert to the much more stable hematite (or goethite). For the reaction

$3 \mathrm{Fe}(\mathrm{OH})_{2} \rightleftharpoons \mathrm{Fe}_{3} \mathrm{O}_{4}+\mathrm{H}_{2}(\mathrm{~g})+\mathrm{H}_{2} \mathrm{O}(l)$

$\left(\Delta \mathrm{G}^{\mathrm{o}}\right)_{\mathrm{r}}=-11.1 \mathrm{kcal}$

$K=\frac{\Delta G_{r}^{o}}{-1.364}=10^{8.1}$

Therefore, $\mathrm{Fe}(\mathrm{OH})_{2}$ is unstable with respect to decomposition into $\mathrm{Fe}_{3} \mathrm{O}_{4}$, water and $\mathrm{H}_{2}$. Under a total pressure of 1 atmosphere, a precipitate of $\mathrm{Fe}(\mathrm{OH})$, should eventually decompose to yield magnetite. Yet both $\mathrm{Fe}(\mathrm{OH})_{2}$ and $\mathrm{Fe}(\mathrm{OH})_{3}$ are compounds of more than transitory existence ${ }^{9}$. For reaction

$\mathrm{Fe}(\mathrm{OH})_{2}+\mathrm{H}_{2} \mathrm{O}(l) \rightleftharpoons \mathrm{Fe}(\mathrm{OH})_{3}+\mathrm{H}^{+}+e$

$\left(\Delta \mathrm{G}^{\mathrm{o}}\right)_{\mathrm{r}}=166.0-(-115.6-56,69)=6.29$

$E^{o}=\frac{6.29}{23.06}=0.272$

$E h=E^{o}+\frac{0.059}{n} \log \left[H^{+}\right.$

$\mathrm{Eh}=0,272-0.059 \mathrm{pH}$

\section{Activities of ions in equilibrium with iron oxides}

The pattern of procedure used is to calculate the activities of dissolved species in equilibrium with iron minerals, for example, reaction envolving hematite and $\mathrm{Fe}^{3+}$

$\mathrm{Fe}_{2} \mathrm{O}_{3}+6 \mathrm{H}^{+} \rightleftharpoons 2 \mathrm{Fe}^{3+}+3 \mathrm{H}_{2} \mathrm{O}$

$\Delta G_{r}^{o}=\left(2 \Delta G_{\mathrm{Fe}(I I I)}^{o}+3 \Delta G_{\mathrm{H}_{2} \mathrm{O}}^{o}\right)-\left(\Delta G_{\mathrm{Fe}_{2} \mathrm{O}_{3}}^{o}+6 \Delta G_{\mathrm{H}^{\prime}}^{o}\right)$

$\Delta G_{r}^{o}=(2 \times-2.53+3 \mathrm{x}-56.69)-(-177.1)$

$\Delta G_{r}{ }^{o}=2.0 \mathrm{Kcal}$

The equilibrium constant is

$\log K=\frac{\Delta G_{r}^{o}}{-1.364}=\frac{2}{-1.364}=-1.43$

$K=\log \frac{\left[F e^{3+}\right]^{2}}{\left[H^{+}\right]^{6}}$ $\log \mathrm{K}=2 \log \left[\mathrm{Fe}^{3+}\right]-6 \log \left[\mathrm{H}^{+}\right]$

$-1.45-6 . \mathrm{pH}=2 \log \left[\mathrm{Fe}^{3+}\right]$

$\log \left[\mathrm{Fe}^{3+}\right]=-0.725-\mathrm{pH}$

If $\mathrm{pH}$ is stipulated, $\left[\mathrm{Fe}^{3+}\right]$ is fixed and vice versa.

\section{RESULTS AND DISCUSSION}

\section{Mineralogical and chemical compositions}

The samples investigated correspond a pisolitic to massive lateritic iron crust (LIC). They show a pisolitic to sphaerolitic framework cemented by microcrystalline matrix and display a brown to red color. The massive LIC presents the same color and the sphaeroliths when present are sub-microscopic and may be broken. The main minerals are goethite, siderite and vivianite ( $\mathrm{Fi}-$ gures 1-2). Kaolinite and hematite are less frequent. Vivianite occurs as centimetric crystals isolated or drusiform. The siderite forms the matrix, replacing the previous goethite and hematite, and replace partly or completely the sphaerolithes or pisolites. It can be found in cavities where it develops large crystal aggregates. The vivianite occurs locally replacing goethite and hematite in the matrix but prefers precipitate along the void between sphaerolithe shells of vivianite and siderite. The large crystals forms preferable along the cavity walls. The textural framework shows that vivianite is formed after the formation of siderite. LIC bearing siderite and vivianite present textures (sphaeroliths and pisolites) and structures indicating dissolution and re-precipitation of iron minerals ( epigenetic alteration ${ }^{7}$.

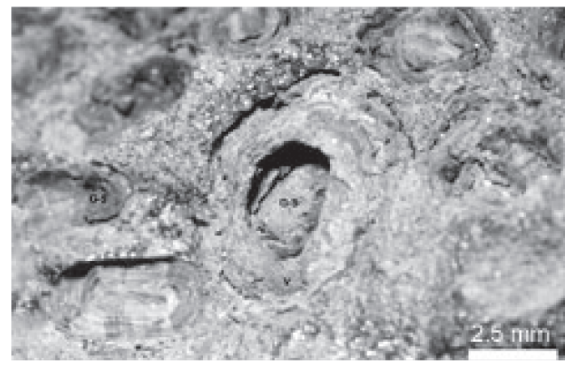

Figure 1. Photomicrograph of the lateritic iron crust. The goethite pisolites $(G)$ were partly to completely replaced by siderite $(S)$ and vivianite $(V)$

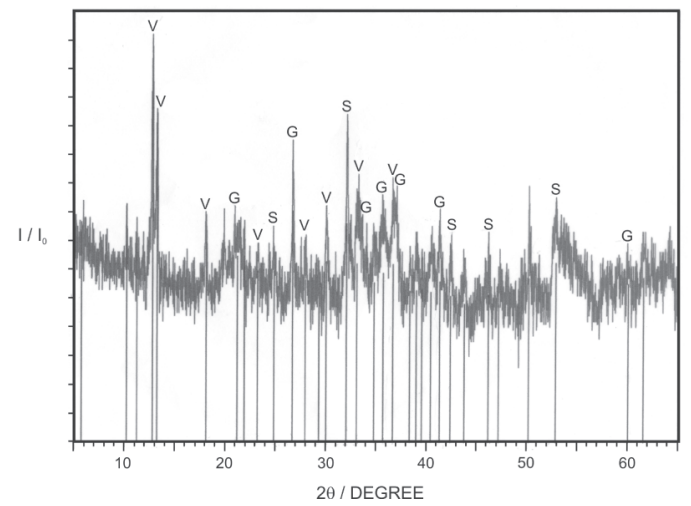

Figure 2. XRD of the pisolites from lateritic iron crust

EDS analysis of siderite in the massive crust show some variations in the chemical composition (Table 2). It was observed 
crystalline vivianite and three varieties in the chemical composition were recognized: Mn-poor siderite (crystalline siderite); siderite and $\mathrm{Ca}$ inclusions (colloforme siderite); and $\mathrm{Mn}$-rich siderite. It is probable that $\mathrm{Ca}^{2+}$ occurs as calcite microscopic inclusions in siderite because $\mathrm{Ca}^{2+}$ can not replace $\mathrm{Fe}^{2+}$. These data indicate that $\mathrm{Mn}$ is the second most common chemical component of siderite. As predicted by ionic radius considerations siderite can be allow a continuous ionic substitution of iron by $\mathrm{Mn}$ (ionic radius of the $\mathrm{Fe}^{2+}$ and $\mathrm{Mn}^{2+}$ are 0.78 and $0,83 \AA$, respectively) until complete solid solution $\mathrm{FeCO}_{3} \_\mathrm{MnCO}_{3}$, and some levels of $\mathrm{Mg}^{2+}(r i=0.72 \AA)$. The $\mathrm{SiO}_{2}$ and $\mathrm{Al}_{2} \mathrm{O}_{3}$ are relatively significant and can be indicate near close relationship to quartz and kaolinite or inclusions of those minerals, the main minerals of the pre-existing lateritic crusts.

\section{Lateritic iron crust: an example of bioreduction}

The dissolution of lateritic crust by microbial catalysis accelerates the process by exerting control over the reaction kinetic and sometimes alters the course of the overall reaction. An example is the reduction of the $\mathrm{Fe}^{3+}$ in the iron minerals such goethite or hematite $^{1-3}$. The inference that bacteria enhance dissolution rates in nature is based on untested assumption that active bacteria have only one function that affects dissolution: they produce soluble dissolutions-promoting complexing ligants. But bacteria may produce dissolution-inhibinting organic compounds as well. Many organic compounds are known to irreversibly adsorb on mineral surfaces or to react with surfaces and solutions to produce stable secondary phase ${ }^{13}$. This adsorption and precipitation may have the effect of limiting the exchange between the mineral surface and the surrounding fluid. In such environments as lakes and swamps of the Amazon region, for example Padauari, takes place: production of humic substances. These substances were originated from the decompositions of organic debris and/or decay of lignin-freealgae ${ }^{13,14}$; the humic substances might sequester organic phosphoruscontaining molecules and render phosphate available through enzymatic hydrolysis. The phosphorus may be also originated from decay of phytoplankton and vertebrate. In the Amazon lakes and swamps are inhabited by rich colony of vertebrates, source of phosphor to water and sediments when they die. Most of the phosphorus within the monapatite inorganic phosphorus (NAIP) fraction is considered to be bonded to poorly crystalline hidrated oxides of iron and manganese, although in strongly environmental and poorly crystalline iron phosphates also may be present. NAIP adsorbed on by hydrated ferric oxides represents the main reservoir of bioavailable phosphorus in suspended particulate ${ }^{13}$; interactions between the lateritic crust, the bottom of the lakes and swanps, with the water and organic matter; biodissolution of the fragments containing goethite and/or hematite coupled humic degradation with liberation of $\mathrm{HCO}_{3}^{-}$and reduction of $\mathrm{Fe}^{3+}$; initial reaction between $\mathrm{Fe}^{2+}$ and $\mathrm{HCO}_{3}^{-}$with formation of siderite and late reaction between $\mathrm{Fe}^{2+}$ and $\mathrm{HPO}_{4}^{2-}$ with formation of vivianite.

\section{Iron minerals equilibria}

On the basis microbiologic reduction of synthetic iron oxides ${ }^{5}$ and thermodynamic data obtained in the previous report ${ }^{9-11}$ an equilibrium Eh-pH diagram was constructed to illustrate the environmental conditions under which vivianite and siderite are stable and are formed (Figure 3). This diagram shows area of dominance for dissolved species $\mathrm{Fe}^{3+}$ and $\mathrm{Fe}^{2+}$ as well as the fields of stability for goethite and hematite, represented as $\mathrm{Fe}(\mathrm{OH})_{3}$, vivianite, siderite, pyrite $\left(\mathrm{FeS}_{2}\right)$ and pyrrhotite $(\mathrm{FeS})$, in systems containing $\mathrm{HPO}_{4}{ }^{2-}$, $\mathrm{HCO}_{3}^{-}$and $\mathrm{HS}$ (modifield after $\mathrm{Hem}^{14}$ and Krauskopf ${ }^{15}$ ).

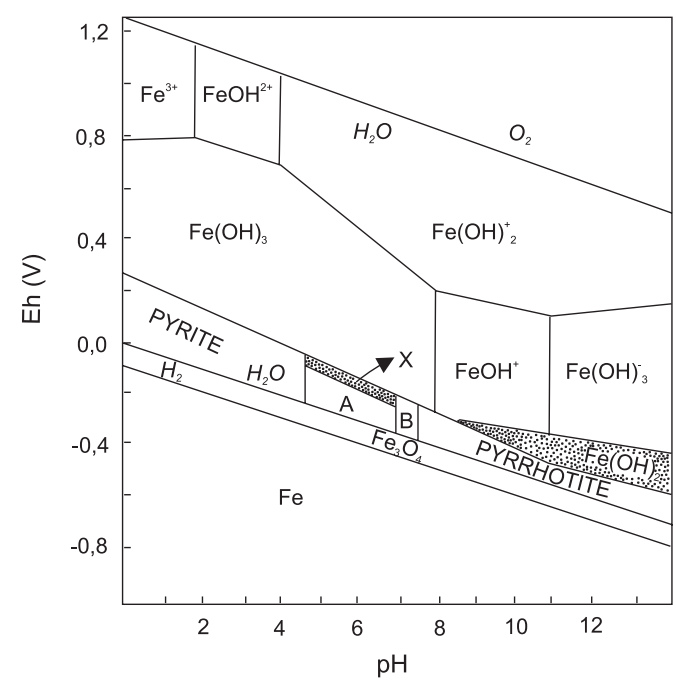

Figure 3. Eh-pH diagram showind stability fields for iron minerals. Vivianite and siderite are represented as $A$ and $B$, respectively

The Eh-pH relations after Garrels and Chritian ${ }^{9}$ and Krauskopf ${ }^{15}$ show that hematite and goethite are the stable minerals of iron in all moderately and strongly oxiding environment; in the reducing environment the stable minerals may be pyrite, pyrrhotite, siderite, vivianite or magnetite, depending on concentrations of sulphur, phosphate and carbonate in the solution; in low HS- concentration, pyrite is stable over a considerable range of Eh and $\mathrm{HPO}_{4}^{2-}$ concentration; it has also been shown that comparatively high ferrous ion activities and moderately high phosphate concentrations are required to stabilize vivianite in most chemical sistems; pyrrotite is teoricatilly stable at low Eh and $\mathrm{HPO}_{4}{ }^{2-}$ concentration. The vivianite is formed under mildly reducing conditions and under high concentrations of available iron and phosphate ions ${ }^{12}$. It can disappear if sulphur concentration is very high and phosphate concentration is very low. The occurrence of siderite is pratically restricted to neutral and basic solutions. It can precipitate from weakly acid solution only if the concentration of dissolved iron is

Table 2. Average chemical composition of the siderite and vivianite (EDS) in the massive crust

\begin{tabular}{lccccccccc}
\hline points & $\mathrm{FeO}$ & $\mathrm{MnO}$ & $\mathrm{MgO}$ & $\mathrm{CaO}$ & $\mathrm{SiO}_{2}$ & $\mathrm{Al}_{2} \mathrm{O}_{3}$ & $\mathrm{Na}_{2} \mathrm{O}$ & $\mathrm{K}_{2} \mathrm{O}$ & $\mathrm{P}_{2} \mathrm{O}_{5}$ \\
\hline 1 & 56.70 & 1.0 & 0.20 & 0.87 & 2.40 & 0.80 & 0.06 & 0.05 \\
2 & 51.00 & 4.45 & 0.10 & 3.85 & 2.40 & 0.50 & 0.05 & 0.05 \\
3 & 43.50 & 12.80 & 0.10 & 1.60 & 1.95 & 0.50 & 0.03 & 0.06 \\
4 & 64.70 & & & & & 0.30 & & 35.70 \\
5 & 61.80 & & & & & 0.50 & & 37.60 \\
\hline
\end{tabular}

1. Crystalline siderite; 2. Microcrystalline (colomorphous) siderite; 3. Mn-rich siderite; 4-5. Crystalline vivianite 
abnormaly high. Within narrow ranges of Eh-pH several pairs of iron minerals are stable together: magnetite-hematite, goethitesiderite, magnetite-siderite, siderite-pyrite ${ }^{5,12,14}$.

The Figure 3 shows two areas indicated by A and B. The A area is the field domain for vivianite and B for siderite stabilitiy. In Padauari it was observed the metastable coexistence of the goethite with siderite and vivianite. This coexistence suggest that from a hypothetical point $\mathrm{X}$ it was initiated the dissolution of the goethite under conditions of Eh near $0.0 \mathrm{~V}$ and $\mathrm{pH}=6-7$. In moderately reducing conditions (near $\mathrm{Eh}=0.1 \mathrm{~V}$ ) and concentration of dissolved iron abnormally high and low sulphur concentration the siderite can be precipitate. The conditions of low sulfide and high phosphate concentrations promotes the formation of vivianite. The field coexistence these minerals (goethite, siderite and vivianite) is very restrict and extends until dashed line, and explains why these minerals are found in very specific environment in Amazon. They are hydromorphic environment formed by swamps and lakes related to lowland and plain landscape developed over low permeable geologic substrate, high rainfall precipitation, a wet tropical climate

In the absence bacterial the reduction of the $\mathrm{Fe}^{3+}$ or $\mathrm{Mn}^{4+}$ never acquires importance because autoreduction is extremely slow and may occur depending on the $\mathrm{pH}$ and $\mathrm{Eh}$ of the milieu. As a result the dissolved species are mostly $\mathrm{Fe}^{3+}$ or $\mathrm{Mn}^{4+}$.

\section{CONCLUSIONS}

The occurrence of vivianite and siderite in Padauari region occupied by extensive hydromorphic environments is more an example of iron minerals formation from the uptake of the lateritic iron crust by presence of aquatic humic substance and microorganisms. This aquatic humic substances are responsible for the over all spreading of black water in the Amazon.

The lakes and swamp from Padauari were favorable for biogenic dissoltion of iron minerals, such as goethite and hematite, where microorganisms can use $\mathrm{Fe}^{3+}$ as electron acceptor coupled humic substances degradation. From these process was originated $\mathrm{HCO}_{3}$ $\mathrm{Fe}^{2+}$ and $\mathrm{HPO}_{4}{ }^{2-}$. The evolution of the siderite and vivianite can be simplified by reactions:
$\mathrm{RHCOHCOO}^{-}+4 \mathrm{FeOOH}+7 \mathrm{H}^{+} \rightarrow 4 \mathrm{Fe}^{2+}+\mathrm{RCOO}^{-}+\mathrm{HCO}_{3}^{-}+$ $6 \mathrm{H}_{2} \mathrm{O} \rightarrow \mathrm{FeCO}_{3}$ (siderite) $+\mathrm{Fe}^{2+}+\mathrm{HPO}_{4}{ }^{2-}+8 \mathrm{H}_{2} \mathrm{O} \rightarrow$ $\mathrm{Fe}_{3}\left(\mathrm{PO}_{4}\right)_{2} .8 \mathrm{H}_{2} \mathrm{O}$ (vivianite) $+2 \mathrm{H}^{+}$

The pairs goethite-siderite and siderite-vivanite are meta-stable under conditions at low $\mathrm{Eh}(-0.3$ to $0.0 \mathrm{~V})$ and $\mathrm{pH}=5.0-7.5$, wich are the new minerals conditions of many ecossystem of the Amazon region, so that it makes possible to find those minerals association in varieties situations these region.

These results show that the formation of siderite and vivianite can be a very common process in the Amazon region, mainly because it carry a lot laterite describing its landscape.

\section{ACKNOWLEDGMENTS}

The authors are grateful to CNPq and CAPES for financial support.

\section{REFERENCES}

1. Lovley, D. R.; Phillips, E. J. P.; Lonergan, D. J.; Environ. Sci. Technol. 1991, $25,1062$.

2. Lovley, D. R.; Woodward, J. C.; Chem. Geol. 1996, 132, 19.

3. Ehrlich, H. L.; Chem. Geol. 1996, 132, 5.

4. Brown, D. A.; Sawicki, J. A.; Sherriff, B. L;. Am. Mineral. 1998, 83, 1419.

5. Zachara, J. M.; Fredrickson, J. K.; Li, S. M.; Kennedy, D. W.; Smith, S. C.; Gassman, P. L.; Am. Mineral. 1998, 83, 1426.

6. Mortimer, R. J. G.; Coleman, M. L.; Rae, J. E.; Geochim. Cosmochim. Acta 1997, 44, 759

7. Costa, M. L.; Lemos, V. P.; REM-Revista Escola de Minas 2000, 53, 101.

8. Costa, M. L.; Lemos, V. P.; Gomes, F. M. S.; Angélica, R. S.; Pöllmann, H.; Aufschlus 2002, 53, 37.

9. Garrels, R. M.; Christ, C. L. Em Solutions Minerals and Equilibria; Garrels, R. M.; Christ, C. L., eds.; Happer \& Roy: New York, Evanstan \& London: John Weatherhell, Inc., Tokyo, 1965, chapter 7.

10. Wagman, D. D.; Evans, W. H.; Parker, V. B.; Halow, I.; Bailey, S. M.; Schumm, R. H.; Nat. Bur. Stand. Tech. Note 1969, 270, 141.

11 Brookins, D.; Eh-pH Diagrams for Geochemistry, Spring-Verlag: Berlin, 1988

12. Nriagu, J. O.; Geochim. Cosmochim. Acta 1972, 36, 459.

13. Manning, P. G., Murphy, T. P.; Can. Mineral. 1999, 32, 459.

14. Hen, J. D.; Geochim. Cosmochim. Acta 1977, $51,527$.

15. Krauskopf, K. B. Em Introductio to Geochemistry; Krauskopf, K. B., ed.; $2^{\text {nd }}$ ed.; McGraw-Hill Book Company: Bogota, 1989. 